\title{
PERLINDUNGAN TERHADAP KONSUMEN DALAM PERJANJIAN JUAL BELI PERUMAHAN (STUDI KASUS PUTUSAN PENGADILAN YANG SUDAH INCRAHT)
}

\author{
Ahmad Hussein \\ Pascasarjana Ilmu Hukum Universitas Lancang Kuning \\ Email: ahmadhussein.sh@gmail.com
}

\section{Info Artikel:}

Diterima: 15 Maret 2020

| Disetujui: 28 Mei 2020

| Dipublikasikan: 30 Juni 2020

\begin{abstract}
Abstrak
Jual beli merupakan suatu perjanjian dengan mana pihak yang satu (penjual) mengingatkan dirinya untuk menyerahkan suatu kebendaan, dan pihak yang lain (pembeli) untuk membayar harta yang telah dijanjiakan. Namun dalam jual beli khususnya rumah pembeli sering kali dirugikan oleh pihak penjual karena ketidaksesuaian kondisi rumah yang telah dijanjiakn. Tujuan penelitian ini adalah untuk menganalisis perlindugan terhadap konsumen dalam Perjanjian pengikatan jual beli perumahan dan untuk menganalisis akibat hukum terhadap pengikatan jual beli perumahan. Metode yang dipergunakan adalah penelitian hukum normatif. Hasil penelitian penulis menerapkan metode berpikir induktif, diketahui bahwa perlindugan terhadap konsumen dalam perjanjian pengikatan jual beli perumahan belum terealisasikan dengan baik karena sebagaimana dijelaskan bahwa sarana perumahan, dan permukiman, maka pihak yang membangun perumahan tersebut wajib menyediakan tempat penyediaan sarana dan prasarana terhadap perumahan. Akibat hukum terhadap pengikatan jual beli perumahan, warga perumahan tersebut dapat menempuh jalur hukum dengan menggugat pelaku usaha dan sekaligus melaporkan pengembang perumahan secara pidana ke Pengadilan.
\end{abstract}

Kata Kunci: Perlindungan Konsumen, Perjanjian, Jual Beli Perumahan

\section{PROTECTION OF CONSUMERS IN THE HOUSING AND SALE AGREEMENT (STUDY CASE DECISION OF COURT THAT HAS BEEN INCRAHT)}

\begin{abstract}
Sale and purchase is an agreement in which one party (the seller) reminds himself to surrender an object, and the other party (the buyer) pays for the promised property. However, in buying and selling, especially houses, buyers are often harmed by the seller because of the incompatibility of the condition of the house that has been promised. The purpose of this study is to analyze consumer protection in the housing sale and purchase binding agreement and to analyze the legal consequences of the housing sale and purchase agreement. The method used is normative legal research. The results of the research the author applies the inductive thinking method, it is known that the protection of consumers in the housing sale and purchase binding agreement has not been realized properly because as explained that housing and settlement facilities, the party who builds the housing is obliged to provide a place to provide facilities and infrastructure for housing. The legal consequences of binding the sale and purchase of housing, residents of these housing estates can take legal action by suing business actors and at the same time reporting the housing developer criminally to the Court.
\end{abstract}

Keywords: Consumer Protection, Agreement, Sale and Purchase of Housing 


\section{A. PENDAHULUAN}

Jual-Beli dalam perkara perdata diatur dalam buku ke-III Kitab Undang -undang Hukum Perdata, Bab ke lima tentang Jual-Beli. Di dalam pasal 1457 yang dijelaskan bahwa yang dimaksud dengan jual beli adalah suatu perjanjian dengan mana pihak yang satu (penjual) mengikatkan dirinya untuk menyerahkan suatu kebendaan,dan pihak yang lain (pembeli) untuk membayar harta yang telah dijanjikan. $^{1}$

Berdasarkan pengertian tersebut dapat dikemukakan lebih lanjut bahwa perjanjian jual beli merupakan perjanjian timbal balik sempurna, dimana kewajiban penjual merupakan hak dari pembeli dan sebaliknya kewajiban pembeli merupakan hak dari penjual. Dalam hal ini, penjual berkewajiban untuk menyerahkan suatu kebendaan serta berhak untuk menerima pembayaran, sedangkan pembeli berkewajiban untuk melakukan pembayaran dan berhak untuk menerima suatu kebendaan. Apabila hal tersebut tidak dipenuhi,maka tidak akan terjadi perikatan jual beli. $^{2}$

Unsur esensial dari sebuah perjanjian jual beli adalah barang dan harga. Harga haruslah diartikan sebagai sejumlah uang

1 Kitab Undang-Undang Hukum Perdata (KUH Perdata).

${ }^{2}$ H.R Daeng Naja, Seri Keterampilan Merancang Kontrak Bisnis, (Bandung : PT. Citra Aditya, 2006), hlm 34 yang digunakan (diakui) sebagai alat pembayaran yang sah sebab apabila tidak demikian, maka tidak ada perjanjian jual beli melainkan adalah perjanjian tukar menukar. $^{3}$

Konsumen diberikan penawaran yang menarik tentang produk rumah pada suatu kawasan perumahan yang dikembangkan oleh developer tersebut, bahkan dengan tawaran adanya potongan harga khusus dan atau hadiah-hadiah menarik lainnya. Cara penyediaan rumah oleh pengembang juga beragam. Ada yang telah tersedia rumahnya terlebih dahulu, calon pembeli bisa memilih rumah sesuai dengan pilihan yang telah tersedia. Ada juga yang rumahnya belum dibangun, akan tetapi diperjanjikan terlebih dahulu antara pengembang dengan konsumen mengenai lokasi dan tipe atau bentuk rumah yang diinginkan. Dalam artian bahwa pengembang juga menyediakan jasa konstruksi kepada konsumen untuk membangun rumah sesuai dengan yang mereka inginkan.

Salah satu hal yang menjadi perhatian konsumen untuk rumah yang belum dibangun adalah spesifikasi teknis dan gambar bangunan rumah itu sendiri. Akan tetapi, seringkali spesifikasi teknis dan gambar tersebut tidaklah secara detil mengemukakan kondisi rumah sebenarnya.

\footnotetext{
${ }^{3}$ Hartono Soerjopratikno, Aneka Perjanjian Jual Beli, (Bandung: PT. Citra Aditya Bakti, 1982), hlm 3
} 
Dalam artian konsumen tidaklah mengetahui secara pasti dan detil kondisi rumah yang sebenarnya, padahal konsumen mempunyai hak seperti yang diatur dalam Pasal 4 Undang-Undang Nomor 8 Tahun 1999 tentang Perlindungan Konsumen mengatakan bahwa konsumen berhak atas informasi yang benar, jelas, dan jujur mengenai kondisi dan jaminan barang dan/atau jasa, dan konsumen juga berhak untuk memilih barang dan/atau jasa serta mendapatkan barang dan/atau jasa tersebut sesuai dengan nilai tukar dan kondisi serta jaminan yang dijanjikan ${ }^{4}$.

Larangan kepada pengembang selaku pelaku usaha untuk tidak memenuhi kualitas bangunan rumah juga sudah diatur sebagai upaya untuk mencegah timbulnya kerugian pada konsumen. Pada Pasal 134 Undang-Undang Nomor 1 Tahun 2011 tentang Perumahan dan Kawasan Permukiman dinyatakan bahwa setiap orang dilarang menyelenggarakan pembangunan perumahan yang tidak membangun perumahan sesuai dengan kriteria, spesifikasi, persyaratan, prasarana, sarana, dan utilitas umum yang diperjanjikan $^{5}$

Pengikatan atau perjanjian ini menunjukkan bahwa adanya hubungan hukum atau hubungan bersifat kontraktual

${ }^{3}$ Undang-Undang Nomor 8 Tahun 1999 tentang Perlindungan Konsumen

${ }^{5}$ UndangUndang Nomor 1 Tahun 2011 tentang Perumahan dan Kawasan Permukiman antara pihak developer dengan pihak konsumen, dimana pihak developer mengikat diri untuk menjual rumah dan tanah kepada konsumen, dan pihak konsumen yang membeli rumah berkewajiban membayar harga jualnya dalam bentuk angsuran uang muka dan sisanya diteruskan.

Namun setelah perumahan terjual, apakah perusahaan perumahan melaksanakan prestasinya dan melindungi dan memenuhi segala kewajiban dan hakhak konsumen. Wujud perlindungan hakhak konsumen seperti hak konsumen terhadap fasilitas-fasilitas perumahan yang dijanjikan, fasilitas listrik dan telepon, semenisasi jalan yang belum, dan juga fasilitas lainnya hingga adanya undian mobil yang belum diberikan serta kekurangan-kekurangan lain yang mempengaruhi kenyamanan konsumen terhadap rumah yang telah dibeli oleh konsumen.

Fenomena diatas menunjukkan banyaknya hak-hak konsumen yang dilanggar oleh pihak pengembang. Lemahnya posisi konsumen dalam hal ini juga turut menjadi faktor pendukung permasalahan diatas dapat terjadi. Meskipun secara jelas pengembang merugikan konsumen dan ingkar terhadap perjanjian antara konsumen dan pengembang. Sementara itu UndangUndang Nomor 8 Tahun 1999 tentang 
Perlindungan Konsumen secara jelas dalam Pasal 4 huruf h mengenai bahwa konsumen mempunyai hak untuk mendapatkan kompensasi, ganti rugi, dan atau penggantian, apabila barang dan atau jasa yang diterima tidak sesuai dangan perjanjian atau tidak sebagaimana mestinya. Ganti rugi yang diberikan oleh pihak pengembang haruslah proposional dan adil dengan kelalaian dan wan prestasi yang dilakukannya. Bentuk ganti kerugian dapat dilakukan perbaikan ulang dan membangun kembali terhadap kualitas rumah yang tidak sesuai pesanan, fasilitas yang dijanjikan terutama ketersedian fasilitas umum dan fasilitas sosial yang dapat membantu konsumen.

\section{B. METODE PENELITIAN}

Jenis penelitian yang digunakan oleh penulis adalah penelitian hukum normatif yaitu penelitian hukum kepustakaan, karena menjadikan bahan kepustakaan sebagai tumpuan utama. Dalam penelitian hukum normatif ini penulis melakukan penelitian terhadap asas-asas hukum yang bertitik tolak dari bidang-bidang tata hukum tertentu, dengan cara mengadakan identifikasi terlebih dahulu terhadap kaidah-kaidah hukum yang telah dirumuskan di dalam perundang-undangan tertentu.

\section{HASIL DAN PEMBAHASAN}

\section{Perlindungan terhadap konsumen dalam perjanjian pengikatan jual beli perumahan}

Sejalan dengan pertumbuhan penduduk yang makin pesat, tuntutan akan tersedianya berbagai fasilitas yang mendukung kehidupan masyarakat juga mengalami peningkatan. Setiap individu selalu berkeinginan agar rumah yang dihuninya memenuhi standar kesehatan, standar konstruksi, tersedianya fasilitas umum, fasilitas sosial dan prasarana lingkungan yang memadai. ${ }^{6}$

Pada dasarnya, ketersediaan sarana perumahan tersebut merupakan kewajiban penyelenggara pembangunan perumahan dan Hal ini dapat dilihat dalam Undang-Undang Nomor 1 Tahun 2011 tentang Perumahan dan Kawasan Pemukiman. Dalam Pasal 19 UndangUndang Nomor 1 Tahun 2011 dinyatakan bahwa penyelenggaraan rumah dan perumahan dilakukan untuk memenuhi kebutuhan rumah sebagai salah satu kebutuhan dasar manusia bagi peningkatan dan pemerataan kesejahteraan rakyat. Penyelenggaraan rumah dan perumahan dilaksanakan oleh Pemerintah, Pemerintah Daerah, dan/atau setiap orang yang menjamin hak setiap warga negara untuk

\footnotetext{
${ }^{6}$ Mursalim, Perencanaan Dan Pembuatan Fasilitas Perumahan, (Jakarta: Citra Adithya Bakti, 2002), hlm 84
} 
menempati, menikmati, dan/atau memiliki rumah yang layak dalam lingkungan yang sehat, aman, serasi, dan teratur. ${ }^{7}$

Perumahan adalah kelompok rumah yang berfungsi sebagai lingkungan tempat tinggal hunian yang dilengkapi dengan prasarana lingkungan yaitu kelengkapan dasar fisik lingkungan, misalnya penyediaan air minum, pembuangan sampah, tersedianya listrik, telepon, jalanan, yang memungkinkan lingkungan pemukiman berfungsi sebagaimana mestinya. Rumah adalah tempat untuk melepaskan lelah, tempat bergaul, dan membina rasa kekeluargaan diantara anggota keluarga, tempat berlindung keluarga dan menyimpan barang berharga. Rumah adalah struktur fisik yang terdiri dari ruangan, halaman dan area sekitarnya yang dipakai sebagai tempat tinggal dan sarana pembinaan keluarga (UndangUndang Republik Indonesia Nomor 1 Tahun 2011). Menurut World Health Organization (WHO), rumah adalah struktur fisik atau bangunan tempat berlindung, di mana lingkungan berguna untuk kesehatan jasmani dan rohani serta keadaan sosialnya, baik untuk kesehatan keluarga dan individu.

\footnotetext{
${ }^{7}$ Soedjajadi Keman, Kesehatan Perumahan Dan Lingkungan Pemukiman, Surabaya: Jurnal Kesehatan Lingkungan, Fakultas Kesehatan Masyarakat Univ. Airlangga, Vol. 2, No. 1, 2005, hlm 30
}

Menurut Suparno Sastra M. dan Endi Marlina, pengertian mengenai perumahan adalah sekelompok rumah yang berfungsi sebagai lingkungan tempat tinggal atau lingkungan hunian yang dilengkapi dengan prasarana dan dan sarana lingkungan. ${ }^{8}$

Menurut Pasal 5 tahun 1974 disebutkan pengertian Perusahaan Pembangunan Perumahan yang dapat pula masuk dalam pengertian Pengembang Perumahan, yaitu: "Perusahaan Pembangunan Perumahan adalah suatu perusahaan yang berusaha dalam bidang pembangunan perumahan dari berbagai jenis dalam jumlah yang besar di atas suatu areal tanah yang akan merupakan suatu kesatuan lingkungan pemukiman yang dilengkapi dengan prasarana-prasarana lingkungan dan fasilitas-fasilitas social yang diperlukan oleh masyarakat penghuninya”.

Dimulai dengan tahap perencanaan, pada tahap ini meliputi izin lokasi, izin perencanaan, Izin Mendirikan Bangunan, serta bagaimana status tanah tempat fasilitas sosial direncanakan. Aspek pengawasan pada tahap perencanaan saat pengembang mengajukan izin pembangunan kompleks perumahan merupakan tahap pengendalian awal. Pengendalian ini diharapkan nantimya dalam tahap pembangunan dapat sesuai

\footnotetext{
${ }^{8}$ Didik Rianto, Perencanaan Dan Pembangunan Perumahan, (Surabaya: PT. Tabah Jaya, 2006), hlm 29
} 
dengan apa yang diajukan sesuai dengan rencana/perizinan yang didapat.

pengawasan dan pengendalian ini dilaksanakan oleh dinas PU dan instansi terkait secara berkelanjutan agar pelanggaran terhadap pembangunan fasilitas sosial dan fasilitas umum dapat dihindari.

Tahap selanjutnya, yaitu tahap penyerahan. Pada tahap penyerahan ini harus sesuai dengan Peraturan Menteri Dalam Negeri Nomor 9 tahun 2009 tentang Penyerahan Prasarana, Sarana, dan Utilitas Perumahan dan Permukiman ke Pemda.. Setelah dilakukan tahap penyerahan sarana, prasarana, dan utilitas umum dari pengembang kepada Pemda, pengembang sudah tidak bertanggung jawab lagi atas kelangsungannya, baik pembiayaan atau pemeliharaan. Segala tanggung jawab sepenuhnya telah berada di pihak penghuni dan Pemda. Selanjutnya apabila ada pengembang, badan usaha swasta dan masyarakat yang ingin melakukan kerjasama untuk pengelolaan fasilitas yang telah diserahkan kepada Pemda untuk keperluan melanjutkan pembangunan perumahannya, seperti diatur dalam Peraturan Menteri Dalam Negeri Nomor 9 tahun 2009 Pasal 22 ayat (3) Nomor 9 tahun 2009 maka diwajibkan memperbaiki dan memelihara fasilitas tersebut sehingga pemeliharaan dan pendanaan fasilitasfasilitas tersebut menjadi tanggung jawab pengelola.

Pembiayaan dalam pembangunan fasilitas sosial seperti diatur dalam Peraturan Menteri Dalam Negeri Nomor 9 Tahun 2009 adalah dibebankan pada harga rumah. Untuk itu pengembang dapat menyediakan fasilitas sosial tyersebut tanpa harus menanggung kerugian yang berarti. Pada hakikatnya, pengembang hanya berkewajiban menyerahkan tanah matang pada Pemda dan Pemda melalui dinas terkait yang akan membangun fasilitas sosial tersebut.

Kewajiban dan tanggung jawab pengembang perumahan terdapat dalam Pasal 19 Undang-Undang Nomor 1 Tahun 2011 dinyatakan bahwa penyelenggaraan rumah dan perumahan dilakukan untuk memenuhi kebutuhan rumah sebagai salah satu kebutuhan dasar manusia bagi peningkatan dan pemerataan kesejahteraan rakyat.

Sebagaimana telah dijelaskan di atas bahwa pemakaman merupakan sarana perumahan dan pemukiman, maka pihak yang membangun perumahan tersebut wajib menyediakan sarana pemakaman. Kewajiban adanya sarana ini juga diperlihatkan dalam Pasal 42 ayat (1) junto. Pasal 42 ayat (2) Undang-Undang Nomor 1 Tahun 2011 yang mengatakan bahwa rumah tunggal, rumah deret, dan/atau rumah susun yang masih dalam tahap 
proses pembangunan dapat dipasarkan melalui sistem perjanjian pendahuluan jual beli. Perjanjian jual beli dilakukan setelah memenuhi persyaratan kepastian atas: (a) status kepemilikan tanah; (b) hal yang diperjanjikan; (c) kepemilikan izin mendirikan bangunan (d) ketersediaan prasarana dan utilitas umum; dan (e) keterbangunan perumahan paling sedikit $20 \%$ (dua puluh persen)

Berdasarkan uraian diatas, dapat dikatakan bahwa pemakaman sebagai salah satu sarana perumahan dan pemukiman, merupakan suatu kewajiban yang seharusnya diperjanjikan juga oleh pembangun. Dalam pasal 134 UndangUndang Nomor1 Tahun 2011, dikatakan bahwa "setiap orang dilarang menyelenggarakan pembangunan perumahan, yang tidak membangun perumahan sesuai dengan kriteria, spesifikasi, persyaratan, prasarana, sarana, dan utilitas umum yang diperjanjikan.

\section{Akibat Hukum Terhadap Perjanjian}

\section{Pengikatan Jual Beli Perumahan}

Berdasarkan Undang-Undang Nomor

1 Tahun 2011 Tentang Perumahan dan Kawasan Pemukiman

Konsumen adalah setiap orang pemakai barang dan/atau jasa yang tersedia dalam masyarakat, baik bagi kepentingan diri sendiri, keluarga, orang lain, maupun makhluk hidup lain. Hak Konsumen adalah hak yang harus dipatuhi oleh para produsen. ${ }^{9}$ Keberadaan konsumen sangat penting bagi suatu keberhasilan dalam usaha, baik dalam perusahaan, ataupun usaha lainnya. Dari tangan konsumenlah kita mendapatkan pundi-pundi uang buah usaha kita atas barang dan jasa yang kita jual atau usahakan.

Hak konsumen wajib diketahui oleh para pebisnis agar para pengusaha atau pebisnis tidak semena - mena dalam memperlakukan konsumen. Jika para pebisnis tidak mematuhinya maka para pebisnis akan mendapatkan ganjaran atau hukuman tersebut bisa sampai ke pengadilan dan yang lebih parah bisa sampai penutupan usaha tersebut.

Kedudukan konsumen terhadap produsen yang seharusnya seimbang menjadi lemah karena rendahnya pengetahuan konsumen akan hak-haknya sebagai konsumen. Konsumen memiliki berbagai macam hak yang seharusnya diperhatikan dan tidak boleh dilanggar oleh para pelaku usaha. Menurut Pasal 4 Undang-Undang Nomor 8 Tahun 1999 tentang Perlindungan Konsumen tersebut terdapat 9 macam hak yang melekat pada konsumen, tetapi hanya empat hak dasar yang diakui oleh Internasional yaitu: (a) Hak untuk mendapatkan keamanan (the

\footnotetext{
${ }^{9}$ A.Z. Nasution, Hukum Perlindungan Konsumen (Suatu Pengantar), (Jakarta: Diadit Media, 2001),hlm 22
} 
right to safety); (b) Hak untuk mendapatkan informasi (the right to be informed); (c) Hak untuk memilih (the right to choose); dan (d) Hak untuk didengar (the right tobe heard);

Hak-hak konsumen ini perlu diketahui oleh masyarakat luas sebagai konsumen, untuk menjamin kepastian hukum dan perlindungan terhadap konsumen. Salah satu unsur pokok kesejahteraan rakyat adalah terpenuhinya kebutuhan perumahan, yang merupakan

kebutuhan dasar setiap Warga Negara Indonesia dan keluarganya, sesuai dengan harkat dan martabat manusia.

Di samping itu pembangunan perumahan merupakan salah satu instrument terpenting dalam strategi pengembangan wilayah yang menyangkut aspek-aspek yang luas di bidang kependudukan dan berkaitan erat dengan pembangunan ekonomi dan kehidupan sosial dalam rangka pemantapan ketahanan nasional. Dalam pasal 1 angka 2 dan 7 Undang-Undang Nomor 1 tahun 2011 tentang Perumah dan Permukiman ditentukan bahwa: "Rumah adalah bangunan yang berfungsi sebagai tempat tinggal, atau hunian dan sarana pembinaan keluarga". "Perumahan adalah kelompok rumah yang berfungsi sebagai lingkungan tempat tinggal atau hunian yang dilengkapi dengan prasarana dan sarana lingkungan dimana manusia tinggal dan melangsungkan kehidupannya".

Pemerintah perlu lebih berperan dalam menyediakan dan memberikan kemudahan dan bantuan perumahan dan kawasan permukiman bagi masyarakat melalui penyelenggaraan perumahan dan kawasan permukiman yang berbasis kawasan serta keswadayaan masyarakat sehingga merupakan satu kesatuan fungsional dalam wujud tata ruang fisik, kehidupan ekonomi, dan sosial budaya yang mampu menjamin kelestarian lingkungan hidup sejalan dengan semangat demokrasi, otonomi daerah, dan keterbukaan dalam tatanan kehidupan bermasyarakat, berbangsa, dan bernegara.

Sebagaimana telah dijelaskan diatas merupakan sarana perumahan, dan permukiman, maka pihak yang membangun perumahan tersebut wajib menyediakan tempat penyediaan sarana dan prasarana terhadap perumahan.

Kewajiban dalam penyediaan sarana dan prasarana terhadap perumahan ini juga diperlihatkan dalam Pasal 42 ayat (1) Jo. Pasal 42 ayat (2) Undang-undang Nomor 1 Tahun 2011 yang mengatakan bahwa rumah tunggal, rumah deret / atau rumah susun yang masih dalam tahap proses pembangunan dapat dipasarkan melalui sistem perjanjian pendahuluan jual-beli. Perjanjian pendahuluan jual beli dilakukan setelah memenuhi persyaratan kepastian 
atas: (a) Status kepemilikan tanah; (b) Hal yang diperjanjikan; (c) Kepemilikan izin untuk mendirikan bangunan induk; (d) Ketersediaan prasarana, sarana, dan utilitas umum; dan (d) Keterbangunan perumahan paling sedikit 20\% (dua puluh persen).

Selain itu, berdasarkan Pasal 45 ayat Undang-Undang Perlindungan Konsumen, dalam hal terdapatnya kerugian akibat tindakan dari pelaku usaha, maka Anda selaku konsumen dapat mengajukan gugatan kepada pengembang melalui lembaga yang bertugas menyelesaikan sengketa antara konsumen dan pelaku usaha atau melalui peradilan yang berada di lingkungan peradilan umum.

Ganti rugi yang diharapkan bisa berupa biaya yang dikeluarkan, biaya yang diakibatkan atas kerugian dan perkiraan keuntungan yang hilang akibat timbulnya kelalaian tersebut. Pembayaran ganti rugi ini harus didahului oleh surat resmi dari pihak yang dirugikan (mengenai kelalaian yang terjadi) terhadap pihak yang lalai.

Akibat hukum yang dapat dilakukan apabila pengembang perumahan wanprestasi atau tidak dipenuhinya akan janji atas penyediaan sarana dan prasarana terhadap perumahan yang dapat dilakukan warga perumahan tersebut adalah menanyakan terlebih dahulu, prinsipnya adalah upayakan untuk menempuh penyelesaian permasalahan ini secara baikbaik. Jika tidak didapat titik temu dalam upaya perundingan tersebut, warga perumahan dapat melayangkan teguran/somasi terlebih dahulu yang isinya mengingatkan pengembang perumahan harus melaksanakan kewajibannya sampai batas waktu yang telah disepakati. Apabila waktu yg telah diperjanjikan terlewati, warga perumahan yang hak atas tempat pemakan tersebut belum terpenuhi, dapat memberikan tenggat waktu kepada pengembang perumahan untuk memenuhi kewajibannya. Jika pengembang perumahan bergeming, warga perumahan tersebut dapat menempuh jalur hukum dengan menggugat pelaku usaha dan sekaligus melaporkan pengembang perumahan secara pidana.

Gugatan dapat dilakukan melalui Peradilan Umum yaitu Pengadilan Umum. Di Peradilan Umum gugatan dilayangkan atas dasar wanprestasi atau ingkar janjinya pihak pengembang perumahan. Dalam gugatan ini, warga perumahan yang tidak terpenuhi hak atas tempat pemakanam dapat menuntut ganti rugi dan juga bunga berupa hilangnya keuntungan yang sudah diperkirakan atau dibayangkan oleh kreditor seandainya tidak terjadi wanprestasi.

Secara pidana, dapat juga

melaporkan pengembang perumahan dengan tuduhan melanggar Pasal 8 ayat (1) huruf F Undang-undang Nomor 8 tahun 1999 tentang Perlindungan Konsumen. 
Pasal ini pada intinya melarang pelaku usaha untuk memperdagangkan barang yang tidak sesuai dengan janji yang dinyatakan dalam label, etiket, keterangan, iklan, atau promosi penjualan barang tersebut. Dalam kasus ini, pengembang perumahan membangun tidak sesuai dengan ketentuan spesifikasi bangunan yang terdapat dalam brosur dan yang telah dijanjikan sebelumnya. Pelaku usaha yang melanggar ketentuan tersebut terancam sanksi pidana paling lama 5 tahun atau denda maksimal dua (2) milyar rupiah. Ancaman sanksi ini termuat dalam pasal 62 Undang-undang Konsumen. Ancaman pidana lain bagi pengembang perumahan yang membangun perumahan yang tidak sesuai dengan kriteria, spesifikasi, dan persyaratan yang diperjanjikan juga diatur dalam Pasal 134 junto Pasal 151 UndangUndang Pasal Nomor 1 Tahun 2011 tentang Perumahan dan Kawasan Permukiman, yaitu denda maksimal 5 milyar rupiah.

Selain sanksi denda, pengembang perumahan tersebut juga dapat dijatuhi sanksi administratif sebagaimana terdapat dalam pasal 150 Undang-undang Perumahan. Sanksinya mulai dari peringatan tertulis, pencabutan izin usaha, hingga penutupan lokasi.

\section{PENUTUP}

Adapun kesimpulan yang dapat diambil dari hasil penelitian yang telah dilakukan oleh penulis antara lain:
Perlindungan Terhadap Konsumen Dalam Perjanjian Pengikatan Jual Beli Perumahan belum terealisasikan dengan baik karena sebagaimana telah dijelaskan diatas merupakan sarana perumahan, dan permukiman, maka pihak yang membangun perumahan tersebut wajib menyediakan tempat penyediaan sarana dan prasarana terhadap perumahan. Dapat dikatakan bahwa penyediaan sarana dan prasarana terhadap perumahan sebagai salah satu perumahan dan permukiman, merupakan suatu kewajiban yang seharusnya diperjanjikan juga oleh si pembangun / pengembang. Dalam Pasal 134 UndangUndang Nomor 1 Tahun 2011, dikatakan bahwa setiap orang dilarang menyelenggarakan pembangunan perumahan yang tidak membangun perumahan sesuai dengan kriteria, spesifikasi, persyaratan, prasarana, sarana, dan utilitas umum yang diperjanjikan. Maka pihak pengembang telah melanggar salah satu pasal dalam Undang-Undang Nomor 8 tahun 1999 tentang perlidungan konsumen.

Akibat Hukum Terhadap Perjanjian Pengikatan Jual Beli Perumahan Berdasarkan Undang-Undang Nomor 1 Tahun 2011 tentang Perumahan dan Kawasan Pemukiman, yang dapat dilakukan apabila pengembang perumahan tidak dipenuhinya akan janji atas 
penyediaan sarana dan prasarana terhadap perumahan yang dapat dilakukan warga perumahan tersebut adalah menanyakan terlebih dahulu, prinsipnya adalah upayakan untuk menempuh penyelesaian permasalahan ini secara baik-baik. Jika tidak didapat titik temu dalam upaya perundingantersebut,warga perumahan dapat melayangkan teguran/somasi terlebih dahulu yang isinya mengingatkan pengembang perumahan harus melaksanakan kewajibannya sampai batas waktu yang telah disepakati. Apabila waktu yg telah diperjanjikan terlewati, warga perumahan yang hak atas tempat pemakan tersebut belum terpenuhi, dapat memberikan tenggat waktu kepada pengembang perumahan untuk memenuhi kewajibannya.

\section{DAFTAR PUSTAKA}

Az, Nasution. "Hukum Perlindungan Konsumen Suatu Pengantar." Yogjakarta (ID): Diadit Media, 2001.

Keman, Soedjajadi. "Kesehatan Perumahan Dan Lingkungan Pemukiman.” Jurnal Kesehatan Lingkungan Unair 2, no. 1 (2005): 3947.

Mursalim. Perencanaan Dan Pembuatan Fasilitas Perumahan. Jakarta: Citra Adithya Bakti, 2002.

Naja, H R Daeng, M H SH, and M Kn. Contract Drafting Seri Keterampilan Merancang Kontrak Bisnis. Citra Aditya Bakti, 2006.

Nomor, Undang-Undang. "Tahun 1999 Tentang Perlindungan Konsumen," $8 \mathrm{AD}$.

Rianto, Didik. Perencanaan Dan Pembangunan Perumahan. Surabaya: PT. Tabah Jaya, 2006.
Soerjopratiknjo, Hartono. Aneka Perjanjian Jual-Beli. Seksi Notariat, Fakultas Hukum, Universitas Gadjah Mada, 1982.

Kitab Undang-Undang Hukum Perdata (KUH Perdata).

Undang-Undang Nomor 1 Tahun 2011 tentang Perumahan dan Kawasan Pemukiman.

Undang-Undang Nomor 8 Tahun 1999 tentang Perlidungan Konsumen 